ISSN 0103-5150

Fisioter. Mov., Curitiba, v. 28, n. 1, p. 61-67, Jan./Mar. 2015

Licenciado sob uma Licença Creative Commons

DOI: http://dx.doi.org.10.1590/0103-5150.028.001.A006

\title{
Does the heel-rise test explain functional capacity in venous insufficiency?
}

\author{
O teste da ponta do pé prediz capacidade \\ funcional na insuficiência venosa?
}

\author{
Danielle Aparecida Gomes Pereira ${ }^{[a]}$, Ana Clara Ribeiro Lages $^{[b]}$, Marluce Lopes Basílio ${ }^{[c]}$, \\ Monize Cristine de Oliveira Pires ${ }^{[c]}$, Débora Pantuso Monteiro ${ }^{[b]}$, Túlio Pinho Navarro ${ }^{[d] *}$ \\ [a] Universidade Federal de Minas Gerais (UFMG), Departamento de Fisioterapia, Belo Horizonte, MG, Brazil \\ [b] Universidade Federal de Minas Gerais (UFMG), Hospital das Clínicas, Belo Horizonte, MG, Brazil \\ [c] Universidade Federal de Minas Gerais (UFMG), Departamento de Fisioterapia, Programa de Pós-Graduação em Ciências \\ da Reabilitação, Belo Horizonte, MG, Brazil \\ [d] Universidade Federal de Minas Gerais (UFMG), Escola de Medicina, Departamento de Cirurgia, Belo Horizonte, MG, Brazil
}

\begin{abstract}
Introduction: Individuals with chronic venous insufficiency (CVI) have muscle pump dysfunction and reduced functionality. However, studies are inconsistent in proving whether a particular test can assess muscle functional capacity. Therefore, the aim of this study was to evaluate whether the heel-rise test (HRT) is able to explain functional capacity in patients with CVI. Materials and methods: Subjects with CVI aged between 20 and 59 years old were selected for this study. All participants were classified by means of the Clinical Anatomy Etiology Pathophysiology Classification of Chronic Venous Disease (CEAP). The HRT and
\end{abstract}

\footnotetext{
* DAGP: PhD, e-mail: danielleufmg@gmail.com ACRL: Grad., e-mail: anaclara.lages@yahoo.com.br MLB: Grad., e-mail: marlucelb@yahoo.com.br MCOP: MSc candidate, e-mail: monize.pires@yahoo.com.br DPM: MSc, e-mail: deborapantuso@hotmail.com TPN: PhD, e-mail: tulio.navarro@gmail.com
} 
the shuttle walk test (SWT) were performed. Descriptive statistics, Spearman correlation, linear models and regression variance analysis (one-way ANOVA) were used for data analysis. Significance was set at alpha $\leq$ $5 \%$. Results: 79 subjects were included in the study ( $38.79 \pm 1.34$ years). The HRT was able to explain functional capacity only in individuals aged between $50-59$ years $(R 2=0.60, p=0.0001)$. The heel-rise test was not sensitive to detect differences between the CEAP classes analyzed ( $p>0.05)$. Conclusion: The HRT was able to explain functional capacity in individuals aged between 50-59 years, and it can be applied in clinical practice for the functional evaluation of patients with CVI with mild severity in this age range.

Keywords: Venous insufficiency. Physical examination. Varicose veins.

\section{Resumo}

Introdução: Indivíduos com insuficiência venosa crônica (IVC) podem apresentar disfunção da bomba muscular e redução de sua funcionalidade. Porém, estudos são inconsistentes em afirmar se um teste específico muscular pode avaliar a capacidade funcional. Sendo assim, o objetivo do presente estudo é avaliar se o teste da ponta do pé (TPP) é capaz de predizer a capacidade funcional em indivíduos com IVC. Materiais e métodos: Foram selecionados para o estudo indivíduos com IVC com idade entre 20 e 59 anos. Os participantes foram classificados por meio da CEAP (Clinical Etiology Anatomy Pathophysiology Classification of Chronic Venous Desease). Foram realizados o TPP e o teste do deslocamento bidirecional progressivo (TDBP). Estatísticas descritivas, correlação de Spearman, modelos de regressão linear e análise de variância (ANOVA one-way) foram utilizados para a análise dos dados. Para significância estatística, foi usado alfa de 5\%. Resultados: Foram incluídos 79 indivíduos (38,79 $\pm 1,34$ anos) no estudo. O TPP foi capaz de predizer a capacidade funcional somente em indivíduos de 50 a 59 anos $\left(R^{2}=0,60 ; p=0,0001\right)$. O TPP não foi sensível em detectar diferenças entre as classes CEAP analisadas ( $p>0,05$ ). Conclusão: $O$ TPP foi capaz de explicar a capacidade funcional em indivíduos de 50 a 59 anos, podendo ser aplicado na prática clínica de forma válida para a avaliação funcional de pacientes com IVC de gravidade leve nessa faixa etária.

Palavras-chave: Insuficiência venosa. Exame físico. Varizes.

\section{Introduction}

Chronic venous insufficiency (CVI) is a dysfunction of the venous system due to venous valvular incompetence, which may or may not occur associated with venous flow obstruction (1). Secondary to poor valvular functioning, the venous hypertension is settled, and it is often associated with muscle pump (1) dysfunction. Composed of the calf veins and surrounding tissue, the muscle pump works to drain venous blood during exercise, reducing venous stasis $(1,2,3)$.

Symptoms and common structural changes resulting from CVI include pain and heaviness in the lower limbs, especially late in the day; hyperpigmentation; lipodermatosclerosis; edema; varicose veins and venous ulcers $(1,2)$. For many patients, CVI represents a reduction of functional mobility and quality of life (1). CVI ulcers result in socioeconomic problems such as loss of work days and early retirement (4).
Early detection and treatment are important to prevent the disease progress and complications (5). One approach is the use of compressive stockings that can minimize complications from venous hypertension, aiding in blood return to the heart and promoting the relief of symptoms (6).

Another approach is to conduct physical therapy that can be performed by means of strength training and endurance of the muscle pump, with the goal of improving venous flow in the lower extremities, which can ensure greater functional performance of individuals with CVI (3). According to Padberg et al. (7), the function and strength of muscle pump improves after a six-month program of exercises to strengthen the calf muscle. The benefit of isotonic exercises has also been described by Kan and Delis (8). This study showed an improvement in the ejection capacity of the muscle pump by increasing endurance and strength of the calf muscle. 
In order to prescribe physical therapy treatment, it is necessary to conduct a targeted assessment. However, clinical examination does not always provide all the necessary information about the anomalies reported by the individual and observed by the examiner (9). Thus, non-invasive tests have been used to further investigate these factors, mainly related to the presence of muscle pump dysfunction (9). Air plethysmography is a noninvasive test that can detect hemodynamic changes in the venous system, by valvular insufficiency or by changes in muscle pump (10). Although this examination provides useful data to evaluate muscle pump function, it is expensive in terms of equipment, time and financial cost.

Therefore, easy to perform and inexpensive tests, such as the heel-rise test (HRT), can be used to infer muscle pump function (11). This test is commonly used in clinical practice to evaluate the function of the calf muscle by counting the number of repetitions of plantar flexion until fatigue (12). In addition to assessing the function of concentric and eccentric mode of the muscle pump, this test also measures the mobility of the ankle joint (13). According to Van Uden et al. (3), individuals with CVI commonly show reduced resistance in the calf muscle, which shows the applicability of the HRT as a tool for evaluating the muscle pump function in CVI.

The weakness of calf muscles can cause disturbances in gait, since this muscle plays an important role during the terminal stance phase (14). The study by Van Uden et al. (3) showed that patients with CVI have reduced gait velocity, which is a determining factor in the functionality of the individual. Pieper et al. (13) observed a positive correlation of performance of plantar flexion with balance $(r=0.38$ to 0.47 ) and gait ( $r=0.38$ to 0.45$)$, and a negative correlation with walking time $(r=-0.30$ to -0.35$)$. However, studies are still inconsistent in demonstrating objectively whether the HRT, being a specific test to evaluate muscle pump, can assess functional capacity. Therefore, the aim of this study was to evaluate whether the HRT is able to explain functional capacity in individuals with CVI.

\section{Materials and methods}

This was a cross-sectional, exploratory and correlational study, approved by the Research Ethics
Committee of the institution in which the study was conducted (CAAE - 0291.0.203.000-11).

Individuals with CVI between the ages of 20 and 59 years, regardless of sex and ethnicity, were selected for the study. Participants underwent clinical evaluation and were classified according to the Clinical Etiology Anatomy Pathophysiology Classification of Chronic Venous Disease (CEAP) (15), including individuals classified as $\mathrm{C} 1$ to $\mathrm{C} 5$. Individuals who had venous ulcers (C6 according to CEAP), peripheral obstructive arterial disease, uncontrolled diabetes mellitus, uncontrolled hypertension, unstable angina, recent pulmonary embolism, acute cardiac events proven by electrocardiogram, heart failure and orthopedic or neuromuscular diseases that limited walking and/or plantar flexion in the standing position were excluded. The sample was recruited by convenience in the city of Belo Horizonte, in the Brazilian state of Minas Gerais.

The tests were performed in the cardiovascular rehabilitation sector of the institution in which the study was conducted. The HRT and the shuttle walk test (SWT), were applied by trained examiners. To conduct the HRT, the reliability of the intra- and interexaminer measurements was assessed. The reproducibility of both the intra- and the inter-examiner was high $(r>0.9 ; p<0.05)$. The order of application of the tests was randomized. A five-minute interval was provided between the tests.

The positioning of the individual in the HRT was defined as proposed by Pereira et al. (16). The test was performed with the subject standing barefoot, in bipodal support and with the dominant hand resting in front of a wall for balance. First, the individual performed plantar flexion until the support over the metatarsal-phalangeal joints for the measurement of the maximum height of plantar flexion. This height was the reference point for all repetitions during the test and the marking was done by an equipment with a rod (16). The subject was instructed to perform the maximum number of complete and consecutive plantar flexions at the greatest possible speed. The examiners recorded the time in seconds and the maximum number of repetitions. When the individual did not reach the maximum height for two consecutive repetitions, the test was finished. The following variables were evaluated in this test: maximum number of repetitions, total time (seconds) and speed (number of repetitions per second).

The SWT, chosen to evaluate functional capacity of the participants in this study, is used to evaluate 
individuals with various health conditions $(17,18,19$, $20,21)$. The protocol for performing the SWT was the modified version developed by Singh et al. (17). Two cones are positioned at a distance of nine meters apart. The test requires the individual to walk from one cone to another, bypassing them. The beginning of the test is marked by a first acoustic signal generated by portable stereo $(19,20)$. Then, signals are sent at regular intervals within which the individual must try to walk all the distance between the cones. At the end of each minute, the time interval between the sound signals decreases, resulting in increased speed. The test is discontinued if the participant does not reach the cone for two consecutive times within the interval between signals, or if their heart rate exceeds $90 \%$ of the maximum rate calculated by age. The heart rate was monitored during the SWT using the Polar" heart rate monitor (Polar Electro OY, Finland). The variables analyzed in this test were the maximum distance (meters) and maximum speed attained (meters/minute).

Descriptive statistics were presented as mean \pm standard deviation, with a confidence interval of $95 \%$. The Kolmogorov-Smirnov test was performed to evaluate data distribution. The correlation between the variables of the SWT and the HRT was assessed by Spearman coefficient. The linear regression model was applied to determine the association between the HRT and the SWT. Analyses were conducted with the total sample and with the sample stratified by age ( 20 to 29 years, 30 to 39 years, 40 to 49 years and 50 to 59 years). One-way analysis of variance (one-way ANOVA) was used for comparison of the HRT between the different classes of the CEAP. A significance level of $5 \%$ was considered.

\section{Results}

Of the 79 subjects in the study, 75 were female, $50.6 \%$ practiced physical activities, $92.4 \%$ reported no functional limitations related to CVI, $96.2 \%$ were non-smokers, $91.1 \%$ did not use compression stockings, $32.9 \%$ were CEAP $1,31.6 \%$ were CEAP 2 and $35.4 \%$ were CEAP 3 . The subjects had a mean age of $38.79 \pm 1.34$, with 20 individuals being assessed in the age groups 20-29, 40-49 and 50-59 years, and 19 subjects aged $30-39$ years. The mean duration of the disease was $11.40 \pm 0.99$ years.

In the HRT, the mean number of repetitions was $72.29 \pm 5.91$ ( $\mathrm{CI}=60.50$ to 84.08), the mean time was $68.24 \pm 6.25(\mathrm{CI}=55.77$ to 80.70$)$ seconds, and the mean speed in repetitions per second was 1.17 \pm 0.49 (CI $=1.07$ to 1.26 ). In the SWT, the mean distance traveled was $584.17 \pm 11.64(\mathrm{CI}=560.96$ to 607.37) meters.

Two linear regression models were used for analysis. In the first model, the number of repetitions and the speed in the HRT were entered as explanatory variables for the distance in the SWT. In the second model, only the speed in the HRT was entered as an explanatory variable. The results of these analyses are shown in Table 1.

The results of the linear regression analyses in different age groups were not significant for 20 to 29 years ( $p=0.13), 30$ to 39 years $(p=0.15)$ and 40 to 49 years $(p=0.45)$. The model showed statistical significance only for the age group from 50 to 59 years (Table 2).

The results of the comparison between the different classes of CEAP in relation to the HRT variables are shown in Table 3.

Table $\mathbf{1}$ - Linear regression considering the total sample of participants

\begin{tabular}{cccccc}
\hline Model & Variables & $\mathbf{p}$ & $\mathbf{R}^{2}$ & Constant & $\mathbf{B}$ \\
\hline 1 & $\mathrm{~V}(\mathrm{HRT})$ & 0.002 & 0.16 & 454.03 & 0.36 \\
& $\mathrm{R}(\mathrm{HRT})$ & & & 88.01 \\
2 & $\mathrm{~V}(\mathrm{HRT})$ & 0.001 & 0.13 & 477.80 & 89.70 \\
\hline
\end{tabular}

Note: $\mathrm{V}(\mathrm{TPP})=$ speed in number of repetitions per second in the heel-rise test; $\mathrm{R}(\mathrm{HRT})=$ number of repetitions in the heel-rise test; $\mathrm{p}=$ level of significance; $\mathrm{R}^{2}=$ determination coefficient. 
Table 2 - Linear regression considering the total sample of participants between 50 and 59 years

\begin{tabular}{cccccc}
\hline Model & Variables & $\mathbf{p}$ & $\mathbf{R}^{2}$ & Constant & $\mathbf{B}$ \\
\hline 1 & $\mathrm{~V}(\mathrm{HRT})$ & 0.0001 & 0.60 & 378.57 & -0.44 \\
& $\mathrm{R}(\mathrm{HRT})$ & & & & 164.44 \\
2 & $\mathrm{~V}(\mathrm{HRT})$ & 0.0001 & 0.58 & 347.27 & 163.22 \\
\hline
\end{tabular}

Note: V $(H R T)=$ speed in number of repetitions per second in the heel-rise test; $R(H R T)=$ number of repetitions in the heel-rise test; $p=$ level of significance; $\mathrm{R}^{2}=$ determination coefficient.

Table 3 - Comparison of different CEAP classes regarding the result of the HRT

\begin{tabular}{cccc}
\hline & R (HRT) & T (HRT) & V (HRT) \\
\hline CEAP 1 & $69.35 \pm 11.42$ & $63.08 \pm 8.57$ & $1.13 \pm 0.07$ \\
CEAP 2 & $66.04 \pm 4.60$ & $67.56 \pm 5.58$ & $1.08 \pm 0.09$ \\
CEAP 3 & $81.28 \pm 10.67$ & $78.25 \pm 13.65$ & $1.20 \pm 0.08$ \\
$F$ & 0.72 & 0.60 & 0.49 \\
p & 0.49 & 0.55 & 0.61 \\
\hline
\end{tabular}

Note: $\mathrm{R}(\mathrm{TPP})=$ number of repetitions in the heel-rise test; $\mathrm{T}(\mathrm{HRT})=$ total time of the heel-rise test; $\mathrm{V}(\mathrm{HRT})=$ speed in number of repetitions per second in the heel-rise test; CEAP $1=$ level 1 in the Clinical Etiology Anatomy Pathophysiology Classification of Chronic Venous Disease (CEAP); CEAP 2 = level 2 in the CEAP classification; CEAP $3=$ level 3 in the CEAP classification; $F=$ one-way ANOVA; $p=$ significance level.

\section{Discussion}

In this study, the HRT was able to explain functional capacity in individuals aged $50-59$ years; however, this result was not found in the entire sample. Furthermore, the HRT was not sensitive in detecting differences among classes 1, 2 and 3 of the CEAP.

The HRT is an instrument that assesses the function of the calf muscle, which is commonly affected in patients with CVI (3). Because this muscle is critical to the good performance of an individual during walking (14), individuals with CVI may show deficits in functional mobility (1) evaluated in this study by means of the SWT.

Age is another factor associated with a reduction in calf muscle function. The sharp decline of muscle mass and strength associated with the reduced functional capacity that occurs with aging $(22,23)$ contributes to the increased prevalence and severity of CVI in older age groups $(1,24)$. Studies evaluating muscle pump function at different ages by air plethysmography showed that muscle pump efficiency decreases with increased age $(25,26)$.

Labropoulos et al. (27), in their evaluation of patients under 60 years of age who had CVI for less than 10 years and did not have a history of deep vein thrombosis, concluded that the hemodynamic changes of this population are more associated with the clinical severity of the disease, since the ejection ability of the calf muscle remained intact in these individuals.

Therefore, characteristics of the study population, such as age less than 60 years and classification at lower levels of the CEAP, only from 1 to 3 , may have weakened correlations between the HRT and the SWT. It is important to emphasize the fact that the sample was constituted of non-elderly adults, what may have been the cause of lower levels of impairment from the CVI in the evaluated population. Additionally, $92.4 \%$ of the studied population stated they did not have functional limitations as a result of the CVI. Thus, it is possible that, in general, these 
individuals did not show deficits in function of the calf muscles enough to cause a significant reduction in functional capacity. In this study, the results found in the isolated analysis of different age groups support this hypothesis, because the HRT was only able to explain functional capacity in the older age group (50-59 years).

A comparison between the different classes of the CEAP in relation to the variables of the HRT showed that this test was unable to detect differences between the three classes analyzed. As the clinical severity of CVI may be related to deficits of the function of the calf muscle $(1,3)$, perhaps the test is sensitive in differentiating individuals classified at more severe levels of the CEAP.

A limitation of this study is the large discrepancy between the frequency of women (94.9\%) and men $(5.1 \%)$ in the sample, which compromises the capacity to generalize the data. However, the prevalence of CVI is higher in women (24). Epidemiological studies suggest the female sex as a risk factor for CVI $(24,28)$.

In this study, to carry out the HRT, the individual was asked to perform plantar flexions at the greatest possible speed until fatigue. Thus, the speed was not pre-determined, leading to greater variability in data. However, standardization of the speed of the HRT was not a clinically feasible choice since the test at lower speeds may result in a ceiling effect in participants with a higher level of physical performance. On the other hand, higher speeds can prevent the realization of the test in people with a low level of physical performance. Thus, the reason for adopting free speed was to reach the greatest number of people.

Through statistical analysis, it was observed that the choice of completing the HRT with free speed was positive, considering that speed was the variable that contributed the most to explaining functional capacity in the age group of 50-59 years. Given this fact, it can be suggested that in order to assess functional capacity in patients with CVI aged 50-59 years with mild CEAP classification, the HRT is not performed until fatigue, but with a pre-determined time, with the guidance that plantar flexions are performed as quickly as possible. Such considerations can be generalized to a restricted age range.

Studies with samples of elderly individuals with greater clinical severity of CVI are necessary to verify whether the HRT is able to explain functional capacity and determine if the test speed remains the main variable to be analyzed.

\section{Conclusion}

The HRT was able to explain functional capacity in individuals from 50 to 59 years of age, with speed being the variable that contributed the most to explain this result. Thus, the HRT can be applied in clinical practice in a valid manner for the functional evaluation of individuals with mild CVI in this age group.

\section{References}

1. França LHG, Tavares V. Insuficiência venosa crônica: uma atualização. J Vasc Bras. 2003;2(4):318-28.

2. Navarro TP, Nunes TA, Ribeiro AL, Castro-Silva M. Is total abolishment of great saphenous reflux in the invasive treatment of superficial chronic venous insufficiency always necessary? Int Angiol. 2009;28(1):4-11.

3. van Uden CJT, van der Vleuten CJM, Kooloos JGM, Haenen $\mathrm{JH}$, Wollersheim $\mathrm{H}$. Gait and calf muscle endurance in patients with chronic venous insufficiency. Clin Rehabil. 2005;19(3):339-44.

4. Aguiar ET, Pinto LJ, Figueiredo MA, Savino Neto S. Úlcera de insuficiência venosa crônica. J Vasc Br. 2005; 4(Supel. 2):S195-200.

5. Kecelj Leskovec N, Pavlović MD, Lunder T. A short review of diagnosis and compression therapy of chronic venous insufficiency. Acta Dermatovenerol Alp Pannonica Adriat. 2008;17(1):17-21.

6. Ibegbuna V, Delis KT, Nicolaides NA, Aina O. Effect of elastic compression stockings on venous hemodynamics during walking. J Vasc Surg. 2003;37(2):420-5.

7. Padberg FT, Johnston MV, Sisto SA. Structured exercise improves calf muscle pump function in chronic venous insufficiency: a randomized trial. J Vasc Surg. 2004;39(1):78-87.

8. Kan YM, Delis KT. Hemodynamic effects of supervised calf muscle exercise in patients with venous leg ulceration: a prospective controlled study. Arch Surg. 2001;136(12):1364-9.

9. Sacchi AA, Castro AA, Pitta GBB, Miranda Junior F. Avaliação da bomba muscular da panturrilha em pacientes portadores de varizes primárias dos membros inferiores através da pletismografia a ar. J Vasc Bras. 2007;6(1):25-34. doi: 10.1590/S167754492007000100005. 
10. Engelhorn CA, Beffa CV, Bochi G, Pullig RC, Cassou MF, Cunha SS. A pletismografia a ar avalia a gravidade da insuficiência venosa crônica? J Vasc Bras. 2004;3(4):311-6.

11. Haber M, Golan E, Azoulay L, Kahn SR, Shrier I. Reliability of a device measuring triceps surae muscle fatigability. Br J Sports Med. 2004;38(2):163-7.

12. Österberg U, Svantesson U, Takahashi I, Grimby G. Torque, work and EMG development in a heel-rise test. Clin Biomech (Bristol, Avon). 1998;13(4-5):344-50.

13. Pieper B, Templin TN, Birk TJ, Kirsner RS. The standing heel-rise test: relation to chronic venous disorders and balance, gait, and walk time in injection drug users. Ostomy Wound Manage. 2008;54(9):26-30.

14. Perry J. Análise de marcha: função normal e patológica. São Paulo: Manole; 2005.

15. Eklöf B, Rutherford RB, Bergan JJ, Carpentier PH, Gloviczki P, Kistner RL, et al. Revision of the CEAP classification for chronic venous disorders: consensus statement. J Vasc Surg. 2004;40(6):1248-52.

16. Pereira DAG, Oliveira KL, Cruz JO, Souza CG, Cunha Filho IT. Avaliação da reprodutibilidade de testes funcionais na doença arterial periférica. Fisioter Pesqui. 2008;15(3):228-34. doi: 10.1590/S180929502008000300003 .

17. Singh SJ, Morgan MDL, Scott S, Walters D, Hardman AE. Development of a shuttle walking test of disability in patients with chronic airways obstruction. Thorax. 1992;47(12):1019-24.

18. da Cunha Filho IT, Pereira DA, de Carvalho AM, Campedelli L, Soares M, de Sousa Freitas J. The reliability of walking tests in people with claudication. Am J Phys Med Rehabil. 2008;86(7):574-82.

19. Cunha Filho IT, Pereira DAG, Carvalho AMB, Campedelli L, Soares M, Freitas JS. Confiabilidade de testes de caminhada em pacientes claudicantes: estudo piloto. J Vasc Bras. 2008;7(2):106-11.

20. Zwierska I, Nawaz S, Walker RD, Wood RFM, Pockley AG, Saxton JM. Treadmill versus Shuttle Walk Tests of Walking Ability in Intermittent Claudication. Med Sci Sports Exerc. 2004;36(11):1835-40.
21. Morales FJ, Martínez A, Méndez M, Agarrado A, Ortega F, Fernández-Guerra J, et al. A shuttle walk test for assessment on functional capacity in chronic heart failure. Am Heart J. 1999; 138: 291-98.

22. Goldspink G. Age-related loss of muscle mass and strength. J Aging Res. 2012;2012:158279. doi: $10.1155 / 2012 / 158279$.

23. Evans WJ, Campbell WW. Sarcopenia and age-related changes in body composition and functional capacity. J Nutr. 1993;123(2 Suppl):465-8.

24. Staffa R. Chronic venous insufficiency - epidemiology. Bratisl Lek Listy. 2002;103(4-5):166-8.

25. Schina Jr. MJ, Neumyer MM, Healy DA, Atnip RG, Thiele BL. Influence of age on venous physiologic parameters. J Vasc Surg. 1993;18(5):749-52.

26. Engelhorn CA, Beffa CV, Bochi G, Pullig RC, Picheth FS, Cunha SS. Avaliação por pletismografia a ar da função da bomba muscular da panturrilha conforme a idade. J Vasc Bras. 2003;2(1):13-6.

27. Labropoulos N, Giannoukas AD, Nicolaides AN, Veller M, Leon $\mathrm{M}$, Volteas N. The role of venous reflux and calf muscle pump function in nonthrombotic chronic venous insufficiency. Correlation with severity of signs and symptoms. Arch Surg. 1996;131(4):403-6.

28. Robertson L, Evans C, Fowkes FG. Epidemiology of chronic venous disease. Phlebology. 2008;23(3):10311. doi: $10.1258 /$ phleb.2007.007061.

Received: $10 / 22 / 2013$ Recebido: 22/10/2013

Approved: 04/28/2014 Aprovado: 28/04/2014 